\title{
Half a pack of cigarettes a day more than doubles DNA breaks in circulating leukocytes
}

\author{
Maneli Mozaffarieh, Katarzyna Konieczka, Daniela Hauenstein, Andreas Schoetzau, Josef Flammer
}

\begin{abstract}
Background: The mechanisms by which smoking induces damage is not known for all diseases. One mechanism believed to play a role is oxidative stress. Oxidative stress leads to cellular damage including DNA damage, particularly DNA breaks. We conducted this study to test the hypothesis that smokers have increased DNA breaks in their circulating leukocytes.

Methods: A comparative quantification of single-stranded DNA breaks was performed by comet assay analysis in the circulating leukocytes of ten healthy smokers (average smoking rate: half a pack a day, range: 9-12 cigarettes a day) and ten age and sex matched healthy non-smokers. DNA breaks lead to smaller pieces of DNA, which migrate out of the nucleus forming a tail during gel-electrophoresis. Damage of an individual cell was quantified by the parameters tail moment and olive moment.

Results: Smoking had a clear effect on both study parameters (tail and olive moment). Smokers had more than double the amount of ss-DNA breaks in their circulating leukocytes than non-smokers [tail moment: $0.75 \mathrm{AU}$

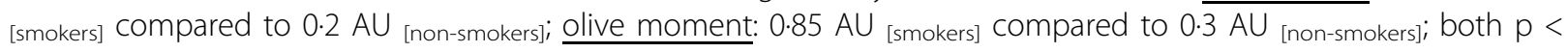
$0.001]$.

Conclusion: Smoking half a pack a day interferes with DNA integrity. One potential explanation for the enhanced DNA breaks in smokers is oxidative stress.
\end{abstract}

\section{Background}

Little doubt exists that smoking is an important risk factor for various

Diseases [1]. Extrapolating from the tobacco-attributed mortality rates in 1995, and taking into account population growth, approximately 3.4 million deaths in developed countries from tobacco is anticipated in 2025 [2]. The exact mechanism by which smoking contributes to the pathogenesis of diseases, like cataracts and agerelated macular degeneration, has not yet been identified in detail. One plausible cause is oxidative stress. The term oxidative stress is widely used in the literature but not very well defined. Oxidative stress occurs when the amount of ROS generated in cells exceeds the capacity of normal detoxification systems [3]. It leads to cellular damage, including DNA damage, in particular DNA breaks.

\footnotetext{
* Correspondence: jflammer@uhbs.ch
Department of Ophthalmology, University of Basel, Mittlere Strasse 91, CH-

* Correspondence: flammer@uhbs.ch
Department of Ophthalmology, University of Basel, Mittlere Strasse 91, CH4031 Basel, Switzerland
} (1)
Under physiological conditions, DNA can undergo spontaneous breaks. DNA damage can occur as doublestrand (ds) breaks or as single-strand (ss) breaks [4]. The number of DNA breaks depends on different factors. For example, it increases with age. Fortunately, DNA damage can be repaired by various mechanisms [5]. As oxidative stress accelerates DNA breaks, we hypothesized that smoking, by inducing systemic oxidative stress, would increase DNA breaks. To investigate this hypothesis we quantified ss-DNA breaks by comet assay in circulating leukocytes of healthy smokers and healthy non-smokers.

\section{Methods}

Subjects

Ten smokers and ten age and sex matched non-smokers were recruited after a notification at the University of Basel informed potential volunteers of the opportunity to participate in a scientific research project. Ethical approval was obtained from the local medical ethics committee, and written, informed consent was received 
from all subjects before admission into the study. The study was designed and conducted in accordance with the tenets of Declaration of Helsinki. The age of the volunteers was between 18 and 60 years. Subjects with any known systemic disease, for example, diabetes, were excluded. In addition, smokers had to have smoked, on average, half a pack of 20 cigarettes a day for at least a year. All subjects were without medications.

\section{Isolation of leukocytes}

Blood samples $(20 \mathrm{ml})$ anti-coagulated with heparin were obtained by venopuncture from the volunteers. The leukocytes were isolated using Ficoll-Histopaque gradients as previously described. The leukocyte bands were removed from the interface between plasma and the histopaque layers of each tube and collected into one $50 \mathrm{ml}$ tube. The total volume was brought to $50 \mathrm{ml}$ with cold Dulbecco's Modified Eagle Medium (DMEM, Gibco $\left.{ }^{\mathrm{TM}}\right)$. The cell suspension was washed three times with DMEM and the total number of cells was determined. Cells were finally suspended in PBS and aliquoted into eppendorf tubes at $10^{7}$ cells/tube.

\section{Comet assay (Single cell gel electrophoresis)}

This simple, sensitive technique permits the detection of single stranded DNA damage in single cells when performed in alkaline conditions. This method has previously been described in detail in literature. The cells under study are embedded in agarose on a slide and subjected to lysis followed by electrophoresis under specific conditions. During electrophoresis, the damaged and fragmented negatively charged DNA migrates away from the nucleus towards the anode. The amount of migrated DNA is a measure of the extent of DNA damage. To detect DNA, the slides are stained with Sybr green and examined by fluorescence microscopy equipped with a personal computer based analysis system which enables quantification of DNA damage. Cells containing damaged DNA have the appearance of a comet with a bright head and tail (Additional file 1, Photo 1). In contrast, undamaged DNA appears as an intact nucleus with no tail (Additional file 2, Photo 2).

\section{Quantification of DNA breaks}

It is recommended by the manufacturers of the comet microscope and imaging software (Nikon AG, Zurich, Switzerland) that 50 cells on each slide be chosen at random for the quantification of DNA damage using the computer software. Tail moment is defined as the product of the tail length and the tail DNA percentage of the total DNA [Tail moment $=$ Tail Length $\times$ Tail DNA/100]. In addition, a function known as olive tail moment was evaluated. Olive tail moment represents the product of the distance between the centers of the mass of head and tail regions and the tail DNA percentage of the total DNA [Olive moment = (Tail meanHead mean) $\times$ Tail DNA/100]. Tail moment and olive tail moment are calculated by the computer software system as an average for the 50 cells selected for measurement.

\section{Statistical Analysis}

The statistical evaluation was done in two steps: first, descriptive statistics, and then a test-statistical analysis. Both were done with the parameter tail moment and olive tail moment. As both parameters were zero-inflated (had many zeros), their distribution was heavy-tailed. The assumptions for usual regression modeling were therefore violated. To overcome this problem, in the test statistics, the fractions of non-zero values compared to the total number of observations were counted for each subject. These fractions were approximately normally distributed. T-tests were performed to compare the results of smokers to non-smokers. A p-value $<0.05$ was considered significant. All evaluations were performed using the SPSS statistical package, $\mathrm{R}$ version $2 \cdot 8 \cdot 1$.

\section{Results}

Smoking had a clear effect on both study parameters (tail and olive moment) (Figure 1). Smokers had a significantly higher amount of ss-DNA breaks in their circulating leukocytes than non-smokers [tail moment: 0.75 AU [smokers] compared to $0.2 \mathrm{AU}$ [non-smokers]; olive moment: $0.85 \mathrm{AU}_{\text {[smokers] }}$ compared to $0.3 \mathrm{AU}$ [non-smokers] ; both

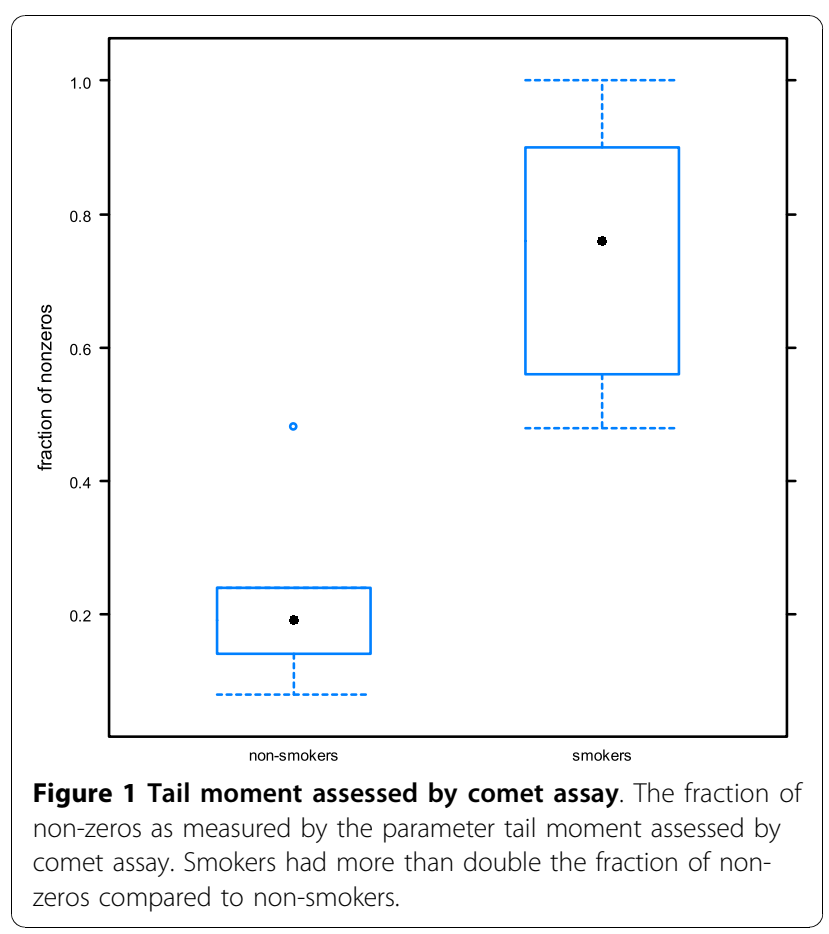


$\mathrm{p}<0.001]$. Table 1 presents the results of the descriptive statistics as well as the differences of means between the study groups, with corresponding $95 \%$ confidence intervals and $p$-values.

\section{Discussion}

Our findings suggest that smokers have a significantly higher rate of ss-DNA breaks than non-smokers. ss-DNA breaks can result from a variety of factors including UV light [6], X-rays [7], ionizing radiation [8], toxins [9], chemicals [10], or by reactive oxygen species (oxidative stress) resulting as by-products of normal metabolic processes [11]. DNA breaks are increased in different human cell cultures when exposed to cigarette smoke [12-15]. Increased DNA breaks have previously also been detected in the leukocytes of smokers [16]. This increase in DNA breaks of leukocytes is not related to the amount of cigarette tar inhaled $[17,18]$.

The increased number of breaks could either be due to an increased incidence of breaks or a decreased repair capacity or both. Theoretically, oxidative stress may give an explanation for both an increased incidence of breaks as well as a decreased repair capacity.

There are several indications pointing towards an increased incidence of oxidative stress in smokers. Oxidative stress in our cells is caused by an imbalance between the production of reactive oxygen species (ROS) and our biological system's ability to neutralize ROS and repair the resulting damage such as DNA breaks [19]. Cigarette smoke contains molecules that act as potent carcinogens (eg. benzo[a]pyrene) [20], as well as a large amount of ROS forming substances such as catechol or hydroquinone [21]. These substances enhance free radical mediated reactions. The actual mechanism's by which smoking induces damage is not entirely known. Various studies support the view of an increased oxidative stress in smokers. Examples include oxidative modifications on muscle proteins [22], oxidative DNA damage in lung tissues [23] as well as in human tracheal smooth muscle cells [24]. Under normal conditions, the ss-DNA breaks are repaired approximately within an hour [25]. It is possible that certain polymorphisms, by affecting DNA repair capacity, enhance the risk for smoking related diseases [26-28].

Smoking also plays an important role in eye diseases. Smokers have, on the average, a higher intraocular pressure [29], cataract at earlier ages [30] and a higher risk for arterial/venous occlusions [31] as well as for agerelated macular degeneration (AMD) [1]. Smokers particularly suffer from the more severe form of AMD, namely exudative (wet) AMD [32].

In summary, smoking half a pack a day more than doubles ss-DNA breaks. We assume the increased number of DNA breaks in leukocytes of smokers to be due to an increased oxidative stress. Further investigations on the role of oxidative stress and DNA repair capacity may have implications for understanding the mechanisms by which smoking induces damage.

Table 1 Results of the descriptive statistics and test statistics

\begin{tabular}{|c|c|c|c|c|c|c|}
\hline \multirow{2}{*}{$\begin{array}{l}\text { Descriptive statistics } \\
\text { Group }\end{array}$} & \multicolumn{3}{|c|}{ Tail moment } & \multicolumn{3}{|c|}{ Olive moment } \\
\hline & non-smokers & smokers & ALL & non-smokers & smokers & ALL \\
\hline Mean & 0.40 & 9.37 & 4.82 & 0.24 & 5.06 & $2 \cdot 61$ \\
\hline Median & 0.00 & 0.44 & 0.00 & 0.00 & 0.54 & 0.03 \\
\hline StdDev & 3.43 & 18.26 & 13.79 & 1.74 & 10.19 & 7.65 \\
\hline IQR & 0.00 & 9.46 & 0.83 & 0.03 & 4.54 & 0.76 \\
\hline Min & 0.00 & 0.00 & 0.00 & 0.00 & 0.00 & 0.00 \\
\hline Max & 52.97 & $115 \cdot 24$ & $115 \cdot 24$ & $27 \cdot 22$ & $62 \cdot 88$ & $62 \cdot 88$ \\
\hline $\mathrm{N}$ & 500 & 485 & 985 & 500 & 485 & 985 \\
\hline Test statistics & \multicolumn{3}{|c|}{ Tail moment } & \multicolumn{3}{|c|}{ Olive moment } \\
\hline Differences of Means* & \multicolumn{3}{|c|}{0.54} & \multicolumn{3}{|c|}{0.48} \\
\hline 95\% C.I. & \multicolumn{3}{|c|}{$0.39-0.68$} & \multicolumn{3}{|c|}{$0.32-0.64$} \\
\hline P-value & \multicolumn{3}{|c|}{$<0.001$} & \multicolumn{3}{|c|}{$<0.001$} \\
\hline
\end{tabular}

The descriptive statistics (based on calculation of raw data) of the tail moment and olive moment in smokers and non-smokers is shown in the upper section of the table. The results of the test statistical analysis in which fractions of non-zero values were compared to the total number of observations have been shown in the lower part of the table.

IQR: Inter-quartile range

* Fraction of nonzeros 


\section{Additional material}

Additional file 1: Photo 1. The cells of the smokers analyzed by comet assay analysis. Each spot represents the DNA of an individual cell. The less bright green "comet-shaped" area adjacent to the nucleus (arrow) represents DNA breaks that are small enough to move in the gel.

Additional file 2: Photo 2 . The cells of the non-smokers analyzed by comet assay analysis. Each spot represents the DNA of an individual cell. The bright green, round spots represent intact DNA. Intact DNA is a large molecule that does not migrate much in the electrophoretic field.

\section{Authors' contributions}

MM recruited volunteers, participated in comet assay analysis and drafted the manuscript. KK carried out comet assay analysis in the laboratory. DH quantified DNA damage. AS performed the statistical analysis. JF conceived of the study, and participated in its design and coordination and helped to draft the manuscript

\section{Competing interests}

The authors declare that they have no competing interests.

Received: 19 August 2010 Accepted: 17 November 2010 Published: 17 November 2010

\section{References}

1. Dhubhghaill SS, Cahill MT, Campbell M, Cassidy L, Humphries MM, Humphries P: The pathophysiology of cigarette smoking and age-related macular degeneration. Adv Exp Med Biol 2010, 664:437-446.

2. Peto R, Lopez AD, Boreham J, Thun M, Heath C Jr: Mortality from tobacco in developed countries: indirect estimation from national vital statistics. Lancet 1992, 339:1268-1278.

3. Halliwell B, Gutteridge JM: Free radicals and antioxidant protection: mechanisms and significance in toxicology and disease. Hum Toxicol 1988, 7:7-13

4. Katyal S, McKinnon PJ: DNA strand breaks, neurodegeneration and aging in the brain. Mech Ageing Dev 2008, 129:483-491.

5. Broyde S, Patel DJ: DNA repair: How to accurately bypass damage. Nature 2010, 465:1023-1024

6. Choy CK, Benzie IF, Cho P: UV-mediated DNA strand breaks in corneal epithelial cells assessed using the comet assay procedure. Photochem Photobiol 2005, 81:493-497.

7. Davidkova M, Juha L, Bittner M, Koptyaev S, Hajkova V, Krasa J, Pfeifer M, Stisova V, Bartnik A, Fiedorowicz H, Mikolajczyk J, Ryc L, Pina L, Horvath M, Babankova D, Cihelka J, Civis S: A high-power laser-driven source of subnanosecond soft X-ray pulses for single-shot radiobiology experiments. Radiat Res 2007, 168:382-387.

8. Stap J, Krawczyk PM, Van Oven CH, Barendsen GW, Essers J, Kanaar R, Aten JA: Induction of linear tracks of DNA double-strand breaks by alpha-particle irradiation of cells. Nat Methods 2008, 5:261-266.

9. Arbillaga L, Azqueta A, Ezpeleta O, Lopez de CA: Oxidative DNA damage induced by Ochratoxin A in the HK-2 human kidney cell line: evidence of the relationship with cytotoxicity. Mutagenesis 2007, 22:35-42.

10. Chye SM, Hseu YC, Liang SH, Chen CH, Chen SC: Single strand dna breaks in human lymphocytes exposed to para-phenylenediamine and its derivatives. Bull Environ Contam Toxicol 2008, 80:58-62

11. $L i \mathrm{~L}$, Jiang $L$, Geng $C$, Cao J, Zhong $L$ : The role of oxidative stress in acrolein-induced DNA damage in HepG2 cells. Free Radic Res 2008, 42:354-361.

12. Albino AP, Huang $X$, Jorgensen ED, Gietl D, Traganos F, Darzynkiewicz Z: Induction of DNA double-strand breaks in A549 and normal human pulmonary epithelial cells by cigarette smoke is mediated by free radicals. Int J Oncol 2006, 28:1491-1505.

13. Moktar A, Ravoori S, Vadhanam MV, Gairola CG, Gupta RC: Cigarette smoke-induced DNA damage and repair detected by the comet assay in HPV-transformed cervical cells. Int J Oncol 2009, 35:1297-1304.

14. Nakayama T, Kaneko M, Kodama M, Nagata C: Cigarette smoke induces DNA single-strand breaks in human cells. Nature 1985, 314:462-464.
15. Sardas S, Walker D, Akyol D, Karakaya AE: Assessment of smoking-induced DNA damage in lymphocytes of smoking mothers of newborn infants using the alkaline single-cell gel electrophoresis technique. Mutat Res 1995, 335:213-217.

16. Dhawan A, Mathur N, Seth PK: The effect of smoking and eating habits on DNA damage in Indian population as measured in the Comet assay. Mutat Res 2001, 474:121-128.

17. Betti C, Davini T, Giannessi L, Loprieno N, Barale R: Comparative studies by comet test and SCE analysis in human lymphocytes from 200 healthy subjects. Mutat Res 1995, 343:201-207.

18. Betti C, Davini T, Giannessi L, Loprieno N, Barale R: Microgel electrophoresis assay (comet test) and SCE analysis in human lymphocytes from 100 normal subjects. Mutat Res 1994, 307:323-333.

19. Halliwell B: Oxidative stress and neurodegeneration: where are we now? J Neurochem 2006, 97:1634-1658.

20. Shi J, Liu B, Xie W: [Modification of mid-point restrictor of heart cut multidimensional gas chromatography-mass spectrometry system and its application in analysis of benzo [a] pyrene in cigarette smoke]. Se Pu 2010, 28:623-627.

21. Moldoveanu SC, Kiser M: Gas chromatography/mass spectrometry versus liquid chromatography/fluorescence detection in the analysis of phenols in mainstream cigarette smoke. J Chromatogr A 2007, 1141:90-97.

22. Barreiro E, Peinado VI, Galdiz JB, Ferrer E, Marin-Corral J, Sanchez F, Gea J, Barbera JA: Cigarette smoke-induced oxidative stress: A role in chronic obstructive pulmonary disease skeletal muscle dysfunction. Am J Respir Crit Care Med 2010, 182:477-488.

23. Asami S, Manabe H, Miyake J, Tsurudome $\mathrm{Y}$, Hirano T, Yamaguchi R, Itoh H, Kasai $\mathrm{H}$ : Cigarette smoking induces an increase in oxidative DNA damage, 8-hydroxydeoxyguanosine, in a central site of the human lung. Carcinogenesis 1997, 18:1763-1766.

24. Cheng SE, Lee IT, Lin CC, Kou YR, Yang CM: Cigarette smoke particlephase extract induces HO-1 expression in human tracheal smooth muscle cells: role of the c-Src/NADPH oxidase/MAPK/Nrf2 signaling pathway. Free Radic Biol Med 2010, 48:1410-1422.

25. Banath JP, Fushiki M, Olive PL: Rejoining of DNA single-and double-strand breaks in human white blood cells exposed to ionizing radiation. Int J Radiat Biol 1998, 73:649-660.

26. Bau DT, Wang HC, Liu CS, Chang CL, Chiang SY, Wang RF, Tsai CW, Lo YL, Hsiung CA, Lin CC, Huang CY: Single-nucleotide polymorphism of the Exo1 gene: association with gastric cancer susceptibility and interaction with smoking in Taiwan. Chin J Physiol 2009, 52:411-418.

27. Sellappa S, Prathyumnan S, Joseph S, Keyan KS, Balakrishnan M, Sasikala K: XRCC1399 and hOGG1326 polymorphisms and frequencies of micronuclei, comet and chromosomal aberrations among tobacco chewers: a South Indian population study. Asian Pac J Cancer Prev 2009, 10:1057-1062.

28. McWilliams RR, Bamlet WR, Cunningham JM, Goode EL, de AM, Boardman LA, Petersen GM: Polymorphisms in DNA repair genes, smoking, and pancreatic adenocarcinoma risk. Cancer Res 2008, 68:4928-4935.

29. Timothy CO, Nneli RO: The effects of cigarette smoking on intraocular pressure and arterial blood pressure of normotensive young Nigerian male adults. Niger J Physiol Sci 2007, 22:33-36.

30. Tan JS, Wang JJ, Younan C, Cumming RG, Rochtchina E, Mitchell P. Smoking and the long-term incidence of cataract: the Blue Mountains Eye Study. Ophthalmic Epidemiol 2008, 15:155-161.

31. Prasad DS, Kabir Z, Dash AK, Das BC: Smoking and cardiovascular health: A review of the epidemiology, pathogenesis, prevention and control of tobacco. Indian J Med Sci 2009, 63:520-533.

32. Seddon JM, Willett WC, Speizer FE, Hankinson SE: A prospective study of cigarette smoking and age-related macular degeneration in women. JAMA 1996, 276:1141-1146.

doi:10.1186/1617-9625-8-14

Cite this article as: Mozaffarieh et al:: Half a pack of cigarettes a day more than doubles DNA breaks in circulating leukocytes. Tobacco Induced Diseases 2010 8:14. 